\title{
Effects of Chlorethanol and Thiourea on the Germination and Relative Yield of the Yam (Dioscorea alata) $\mathrm{L}^{1}$
}

\author{
Hector R. Cilses and José Adsuar ${ }^{2}$
}

\section{INTRODUCTION}

Yams are an important anficle of our diet and bring relatively good prices in stores in Puerto Riro. Lloride ${ }^{3}$ yan (Dioscorea alata) $\mathrm{L}$. is ono of the most widely and commonly planted varieties in the Island, and is perhaps second in popularity to the Habanero variety. In general, yam seeds (tubers) are noted for their prolonged rest or dormanti period. In the Florido variety it is considered necessary to wait for about 3 or 4 months after harvest, before they can be expected to germinate after planting.

Dormancy is convenient: from the marketing and storing standpoint, because it gives the farmer more time to dispose of the crop. Dormancy can be increased further by piling the newly harvested roots in cool, shady places and subsequently covering them cither with sand or chareotl dust. Paraffining them also fonds to increase their storage life. However, agrononicully spoaking, dormaney considerably limits the opportunity or possibility of initiating new plantings from freshly harvested yams. In fact, after selecting the secds for the next planting, farmers bave to keep them stored throughout the durat ion of the prolonged rest period of some months. In addition to the inconvenience of waiting during the long storage periods the seed tubers are exposed to pests and diseases. Customarily firmers wait until the seed start to germinate before they are planted in the field. Yam secds are solected from among the smallest roots, usually weighing 6 to 8 ounees wach.

\section{OHJECEIVE}

This long dolay in starting new plantings, caused by the long dormancy of the soed, forces yam growers in Puerto Rico to plant at about the same date within all their respective areas. Accordingly, the harvestimes ior the eurrent-year crops from all areas more or less coincide. This ereates

\footnotetext{
1 The worl "yam" as used here is the English equivalent of the name in Spanish or nyami in Senegalese to designate the tuberous root from Dioscorca spp.

${ }^{2}$ Plant Physiologists, $\Lambda$ gricultural dxperiment Station, University of Puerto Rico, Río Piedras, P.1R.

"The Florilo variefy was being used in research along other lines and a good supply of seed was at hand for these studies. It should be noted that other varieties have the same habit of long dormancy that is so well known in Florido.
} 
rolatively low prices to the growers, since their produce will reach the market in large quantities all at the sime time. This unfortunate glut is wasteful and results in lot and market losses. If any high prices are obtained, they will exist for short periods only at the beginning and at the end of the cropping soason, when yams are searce. 'Thus, overcoming the rest period in the Florido or any other important yam varioty by some chemical means would be of considerable exonomic importance to farmers. By so doing it would be possible for them to schedule or spread their future plantings through a longer season, which would have a corresponding effect upon the harvestime and market oullook. Such was the major objective of this investigation.

\section{MATERIALS AND METILODS}

Chemicals have been extensively uscd to solve dormancy problems in other crops, such as: Potato tubers, gladiolus bulbs, and Jerusalem-artichokes. Quite a number of chemical products have received attention from research workers in this respect $(1)^{4}$. Among them the following can be mentioned: Ethylene chlorohydrin, (chlorethanol); sodium, potassium, and ammoniun thiocyanates; thiourea, ether, elhylene, and chloroform. 'The dip, soak, and vapor methods were studied in evaluating their effectiveness.

Work was started in 1955 at this Station to determine whether a similar response could be induced in the lilorido yams through application of chemicals, and two were selected as very promising for this purpose, ethylene chlorohydrin and thiourea. However, in a preliminary test Florido yam had not responded to the separate or individual applications of either chemical. Similar results had previously been seeured by Denny (4) with some gladiolus varieties. On the other hand, when he treated them simultaneously with the chlorethanol and thiourea solutions, they germinated promptly. Tollowing Denny's approach lilorido yams wor: used to study the effects of more detailed conseculive troatments with the chemicals.

Each chemical was dissolved in water at three different concentrations: Chlorethanol at 40,50, and $60 \mathrm{ml}$./liter of solution and thiourea at $0.5,1$, and 2 percent. The above sels of solutions were factorially combined jnto nine different treatments, all of which are shown in tablo 1.

A group of 50 medium-sized uniform yams were treated under cach combination of solutions. They wore first immersed in the ohlorethanol solution for 5 minutes, after which they were transferred to the corresponding thiourea solution where they remained for 2 hours. One lot was soaked in tapwater without ehemicals for 2 hours also. At the end of the soaking

\footnotetext{
4talic numbers in parentheses refer to Literature Cited, p. 208.
} 


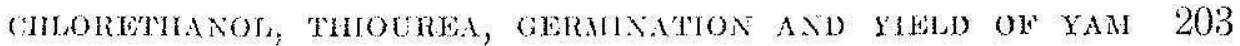

TABse 1.--Efoct of treatments on the germination and number of sprouts developed by filorialo yams, 1955

\begin{tabular}{|c|c|c|c|c|c|c|c|c|}
\hline \multirow{2}{*}{ 'Treatments } & \multirow{2}{*}{$\begin{array}{c}\text { Yams } \\
\text { treaterl }\end{array}$} & \multicolumn{5}{|c|}{ Germination and sprouts by date } & \multirow{2}{*}{$\begin{array}{l}\text { Averagc } \\
\text { sprouts } \\
\text { per yam }\end{array}$} & \multirow{2}{*}{$\begin{array}{l}\text { Yield } \\
\text { (cape) }\end{array}$} \\
\hline & & Jan. 31 & $\mathrm{Feb} .4$ & Fob. 25 & Mar. 23 & Apr. 30 & & \\
\hline & Number & Number & Number & Nomber & Nombler & Number & Number & Posinds \\
\hline $\begin{array}{l}\text { Chlorethanol } 40 \mathrm{rnl} . / \\
\text { liter of solution, } \\
\text { thiourea } 0.5 \text {-pereent } \\
\text { solution }\end{array}$ & 50 & 1 & 4 & 14 & 30 & 149 & 2.98 & 18 \\
\hline $\begin{array}{l}\text { Chlorethanol } 50 \mathrm{ml} \text {./ } \\
\text { liter of solution, } \\
\text { thiourea } 0.5 \text {-percent } \\
\text { solution }\end{array}$ & 50 & 8 & 11 & 22 & 37 & 158 & 3.16 & 17 \\
\hline $\begin{array}{l}\text { Chlorethanol } 60 \mathrm{ml} . / \\
\text { liter of solution, } \\
\text { thiouren } 0.5 \text {-pereent } \\
\text { solution }\end{array}$ & 50 & 10 & 12 & 30 & 57 & 215 & 4.30 & 22 \\
\hline $\begin{array}{l}\text { Chlorethanol } 40 \mathrm{ml} . / \\
\text { liter of solution, } \\
\text { thiourea } 1 \text {-pereent } \\
\text { solution }\end{array}$ & 50 & 1 & 1 & 12 & 23 & 171 & 3.42 & 14 \\
\hline $\begin{array}{l}\text { Chlorethanol } 50 \mathrm{ml} . / \\
\text { liter of solution, } \\
\text { thiourea l-percent } \\
\text { solution }\end{array}$ & 50 & 3 & 7 & 19 & 31 & 201 & 4.02 & 22 \\
\hline $\begin{array}{l}\text { Chlorethanol } 60 \mathrm{ml} \text {./ } \\
\text { liter of solution, } \\
\text { thiourea 1-percent } \\
\text { solution }\end{array}$ & 50 & 5 & 6 & 17 & 33 & 170 & 3.40 & 26 \\
\hline $\begin{array}{l}\text { Chlorethanol } 40 \mathrm{ml} . / \\
\text { liter of solution, } \\
\text { thiourea } 2 \text {-percent } \\
\text { solution }\end{array}$ & 50 & 8 & 15 & 31 & 58 & 211 & 4.22 & 24 \\
\hline $\begin{array}{l}\text { Chlorethanol } 50 \mathrm{~mL} . / \\
\text { liter of solution, } \\
\text { thiourea 2-percent } \\
\text { solution }\end{array}$ & 50 & 4 & 12 & 28 & 43 & 180 & 3.60 & 28 \\
\hline $\begin{array}{l}\text { Chlorethanol } 60 \mathrm{ml} . / \\
\text { liter of solution, } \\
\text { thiourea } 2 \text {-percent } \\
\text { solution }\end{array}$ & 50 & 3 & 15 & 29 & 43 & 184 & 3.68 & 12 \\
\hline Check & 50 & - & - & - & 4 & 113 & 2.26 & 4 \\
\hline
\end{tabular}

1 Preliminary harvest or "cape" of yams is normally made about 8 months after being planted. 
period yams were romoved from the solutions or tapwater and placed in paper bags and labelled. Those soaked in tapwater were kept in the open. The rest, after soaking and then drying, were stored for a period of 2 thours in a lightly closed comparment in the laboratory. Noxt day (Jan. 7, 195i) they were planted in the field aceseding to established agronomic puartices.

Periodie sprout counts wore made as sprouts emerged from the soil. This was carried on for 5 months and then discontinued. Wight months from the planting date a "cape" was pertormed. A cape jis the nsual proliminary havest of well-developed yams from good vines approthehing maturity. These are often somewhat out of season and are sold at a high price, or may be saved for planting puposes. Roots from the cape were weighed and tho woights considered as a eriterion to evaluate the effect of treatmonts wyon yiclds.

\section{RESLLIS}

Tablo 1 shows the data gathered on the effect of the various treatments on the germination, number of sprouts, and yicld of Elorido yams. As can be observed, all the chemically treated yams, irrespective of the chlorethanol-thiourea combination received, started to sprout in about a month, or shortly after they were planted. From there on sprouting continued steudily until counts were discontinued on April 30 . However, it took nearly 4 months for untrented roots to germinate (see fig. 1). The chenically treated yams not only germinated sooner than the unl roated ones, but they produced a larger number of sprouts as well. In some instances this difference amounted to more than 10 perent.

Apparently the chlorethanol-thiouren treaments not only stimulated early sprouting, but also induced several shoots to grow from each eye. Both chemicals have proved to be capuble of inducing such reactions by Denny (2,3), who observed the formation of inuliple sineouting of potato and glidiolus after treatmont with thourea and chlorethuol, respectively. According to his results, not all of the shoots devoloped fully; some died baek. In our experiments with yam this did not take place sime all shoots grew into healthy vines (see fig. $1, B$ ).

The yield differences between the reated and untreated yams were striking. The untreated yams produced t pounds, while the lowest yield for the chemically troated ones was 12 pounds of edible roots. This oceured under the strongest chlorethanol-ihouren combination. 'The highest yield, on the other hand, occured under the treatment ronsisting of $50 \mathrm{ml}$. of: ehlorethanol and 2 pereent of thiouren. The wide differenees in yield among treated and untreated seeds would sem to us to be atribut ed to the fact that the former started growth entier and more profusely than the latter (soe fig. 2). 


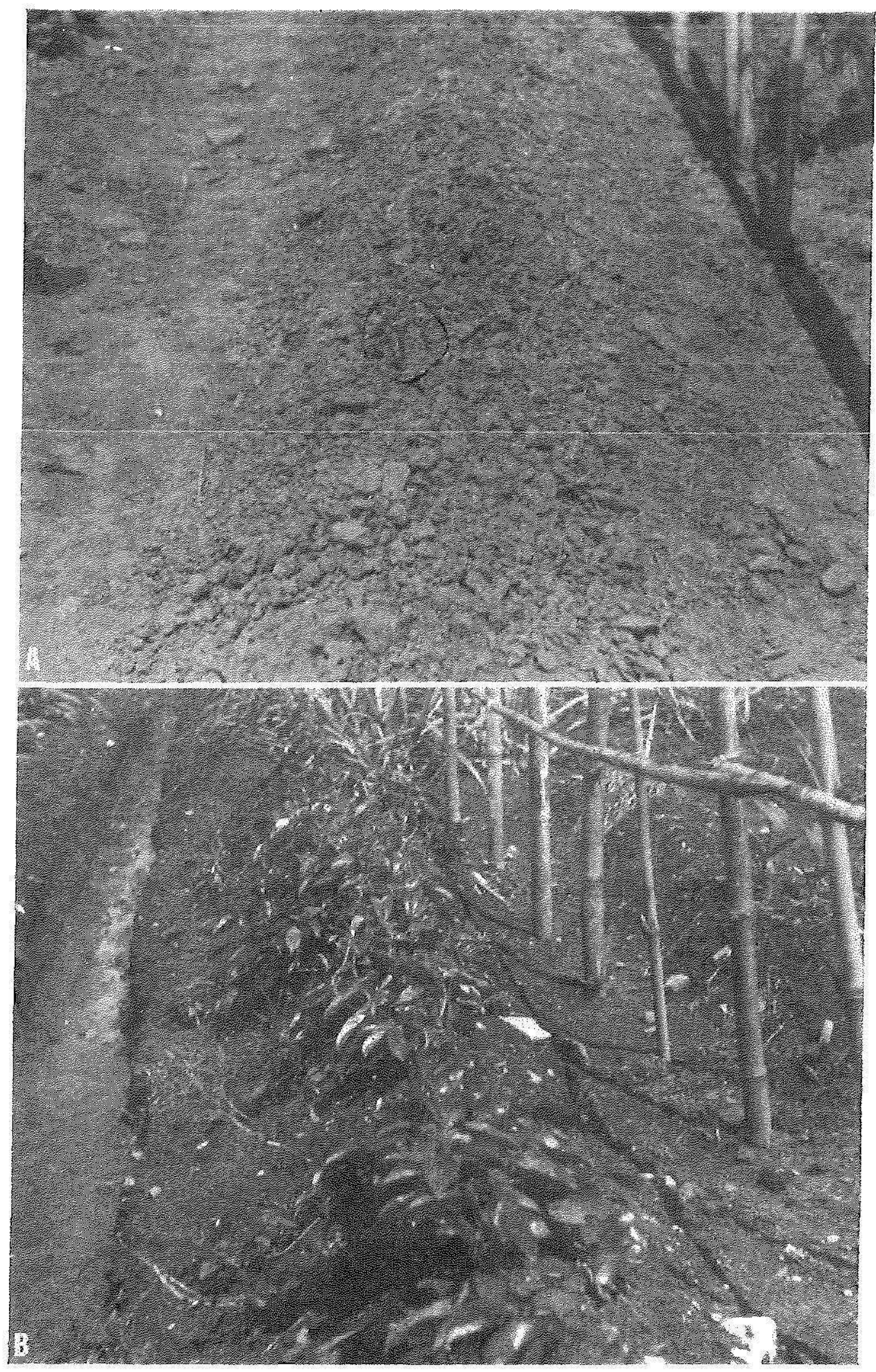

Fig. 1.- $A$, Plot of untreated Forido yans, 4 montles after planting; 3 , same as in $\mathrm{A}$, but trented with chlorethanol and thiomea. 
The effects of the various chenical leatments unon the number of sprouts were not too consistent. However, there was a sendency for the number of sprouts to incease with an increnses in the chlorethanol concen tration. The trend also was towards more sijnouts as fle encentration of thiourea was raised.

On the other hand, the differen'es in yiold as influenced by variations in the chlorethanol concentrations were somewhat moro conclusive. Again

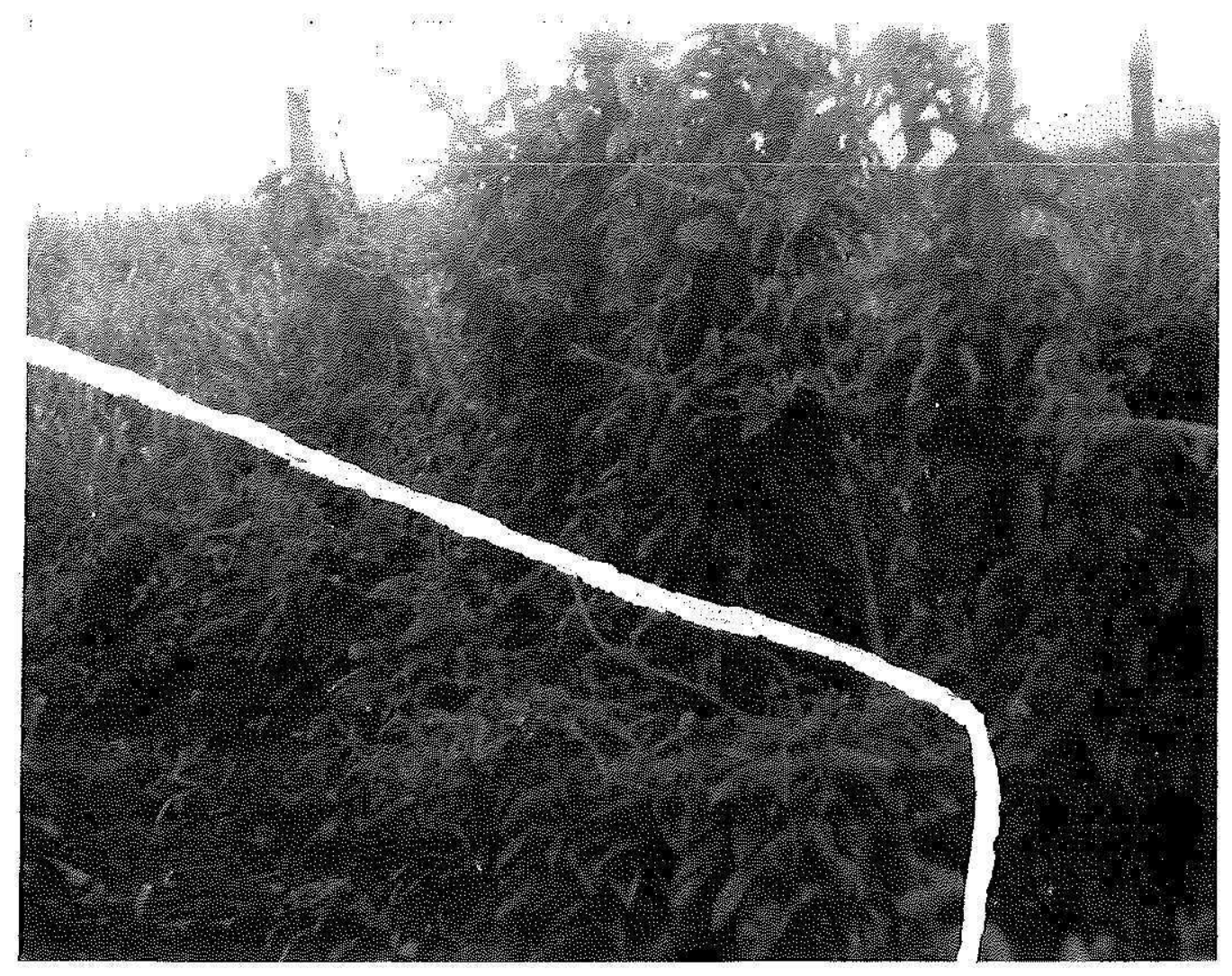

FIg. 2,-This pirture shows the diflerence in growth betwecu untrealed flett) and treated yams (right) hefore the (appe was performed.

the tendency was for the yould to increase from the lower to the highest chlorethanol level. The production of edible yanss was not appreciably affected by the level of the thioura used. However, if we refer to table 1, we notire that the best and third-best production of roots oesurred under medium and low (h)lorethanol-high thiourea terentments. Conversely, the lowest yield cune under the highest chlorethanol-thiourea solution. Thus, it seems mrobable that this treatment resulted in a somowhat toxir effert upon the development of edible roots, even though the number of sprouts produced wis retatively high. 


\section{CONCLUSTON}

According to the above-described results it can be concluded that the most effective eombination of chlorethand thourea solutions for braking the rest period in the Florido yam variety, and at the same time attaining a large number of sprouts, and a high yich of roots, are the modium chloref hanol-high thiourea or the high chlorethanol-medium thourea solutions.

\section{SUMMARY}

Groms of 50 modium-sized uniform Florido yams were conseculively trated with varous factorially combined rhlorethmol-thourca solutions. The chlorethanol was used at rates of 40 , 50 , and $60 \mathrm{ml}$./ liter of solutiou, while the thiourea solutions were prepared at $0.5-, 1$, and 2-perent conrentrations. The most important lesults wore as follows:

1. All treated yam "seed" stated to sprout in aboul a month, or shortly after they were planted in the field. It took nearly 4 months for the untreated seed to germinate.

2. Besides stimulating ealy spouting the chloretholdhomea treatments also induced several shoots to grow from anch bud.

3. Ticld differences between treated and untrented yams were outstanding. Untrouted yans produeed only + pounds, while the lowest yield for the chemically teated yoms was 12 pounds of edible roots.

4. There was a lendeney for tho number of sprouts and the yield to increase with an incrcase in tho chlorethanol concentration. No such affects were apparent from the thiomea concentrations.

\section{BKSUMEN}

Se trataron varios grupos do j0 tubéreulos de name de la variedad Florido, ada uno do tamaño mediano, con soluciones de clonetanol y tiourea conseculivamente, de acuerdo con el sistema factorial. Fl cloretanol se usó a razón de 40,50 y $60 \mathrm{ml}$. por litro de solución, mientras que la tiourea se preparó a base de $0.5,1$ y 2 yor ciento. Los resultados más importantes que se obtuvieron se mencionan a conimunción:

1. Todas las "semillas" de namo gue recibieron los tratamientos empoyaton a germinar un mes más tarde, o sea, poco después de sembrarse en pleno campo. Por el contrario, las semillas sin tratar tardaron 4 meses on geminar.

2. Además do estimular una germinación fempuana, los tratamientos con elocetanol y tiourea también indujeron el desarrollo de varios brotes yor yema.

3. Jas diferencias en rendimiento entre los names tratados y los no tatados fueron considerables.

4. Los resultados indicaron que a myor concentración de cloretanol, 
mayor fue la tendencia a aumentar al numero de brotes y el rendimiento. En cambio, la ioura aparentemente no causó tales efoctos.

\section{LITERATUIE GTIED}

1. Avery, G. S., and Johnson, E. B., Hormones and Horticulture, MeGraw-Hill Bork Co., Tuc., New York, N.Y., 1st ed., 1947.

2. Denny, F. E., Enect of thiourea upon bud inhibition and apical dominance of potato, Bol. Gaz. 81: 297-311, 1926.

3. - - Shortening the rest period of gladioulus by treatment with chemicals, Amer. J. Bot. 17: 602-13, 1930.

4. - - - personal communication, 1954. 